\title{
Acerca dos Universais e da Teoria da Suppositio de Guilherme de Ockham
}

Eligia Hirano Tunis Martins (DF/USP/SP)

Orientador: José Carlos Estevão

\section{Introdução: Uma Questão}

A disputa dos universais emerge com grande força entre os medievais e recupera a antiga oposição: Platão e o seu mundo das idéias'; e Aristóteles, com um resíduo platônico, que desce as idéias platônicas, de topos Uranos, para o mero mundo das coisas terrestres. Aristóteles enfrenta Platão na questão da singularidade do problema dos universais, ou seja, a real natureza dos universais, mas não explicita alguns de seus conceitos, suscitando dúvidas ${ }^{2}$ Portanto, as interpretações divergem, e essas divergências reportam-se (ainda que involuntariamente e mesmo a contragosto de muitos aristotélicos) a este ponto nevrálgico dentro do sistema peripatético, revelando uma "incerteza interna" sobre os universais. De tal sorte que percebe-se os reflexos desta incerteza, justamente nos vários comentadores desta questão.

Por certo, muitas interpretações foram feitas a respeito dos universais e a maior preocupação consistia em estabelecer o que se entendia ser a natureza destes universais. Sendo assim, várias perguntas foram levantadas a partir das três questões de Porfírio: "no que se refere aos gêneros e às espécies, a questão de saber se elas são realidades em si mesmas, ou apenas simples concepções do intelecto, $e$, admitindo que sejam realidades substanciais, se são corpóreas ou incorpóreas se, enfim, são separadas ou se apenas subsistem nos sensiveis"4. Podemos traduzir estas questões por: é o universal na substância? e se for uma substância, é ele próprio de algum indivíduo? Ora, se o universal é a substância de um indivíduo, então este indivíduo será todos os indivíduos?

Para os "realistas" isto é, de Guilherme de Champeaux a Duns Escoto, com as devidas distinções ${ }^{5}$ - o universal é de certa maneira na coisa, como forma ou substância; logo, os "realistas" o são por declararem a existência de "realidades universais"

Por outro lado, a solução de um Ockham, após várias outras posições "nominalistas" apresenta uma nova face. Além de apresentar o universal com a função lógica de predicabilidade como fizeram outros "nominalistas" ele ainda sustenta que o universal não é uma convenção de palavras, mas um conceito mental, um ato intelectivo. Isto significa que o universal tem existência na mente, contudo estes conceitos singulares na mente supõem pelas coisas extramentais, ou seja, o universal afirma a sua universalidade remetendo-se a coisas individuais.

Disto se segue, que o tratamento dos universais se resolve pela teoria da suppositio. Não é nossa intenção, no momento, levantar as oposições que se afiguram em relação a esta concepção sobre os universais, ao contrário, o empenho vai na direção de fazer uma leitura do que Ockham diz sobre o tema e a importância da 
suppositio para poder fundamentar o conceito de universal.

\section{II. - Desenvolvimento: Os Universais}

A posição adotada por Guilherme de Ockham se ocupa: primeiro em provar que "nenhum universal é uma substância existente fora da alma"; em segundo lugar, argumenta que "o universal é uma intenção da alma" e conclui contra universale ante rem. Com isso, descarta as diversas formas de realismo e esforça-se em demonstrar que seus opositores cometeram um erro fatal conferindo realidade extramental ao universal.

Precedendo a todos os argumentos, Ockham declara: "nenhum universal é uma substância singular, numericamente una" e inversamente "nenhuma substância singular é universal", logo "toda substância é numericamente una e singular" Entretanto, diz ele: "Não basta afirmar tais coisas sem as provar por uma evidente razão" e é então o que vai fazer, juntando vários argumentos e citando as autoridades, para dar assentimento à sua proposição.

No primeiro argumento ele se empenha em mostrar que Sócrates que é uma coisa extramental é "uma substância singular, numericamente una" não podendo ser um universal. Ora, se o universal fosse qualquer coisa singular, incorrer-se-ia no absurdo de que Sócrates seria um universal. Logo, toda substância é numericamente una e singular, e nenhuma substância singular é universal. Na verdade, ele enfrenta a hipótese da substância ser "uma coisa" ou "várias coisas" e lança a sua navalha para cortar a multiplicidade. Ou seja, se é "uno" é o que ele quer, então é singular; e, se são "várias coisas", então repetimos o processo: tomamos a coisa, vemos se é "uma" ou "várias" e assim ao infinito, portanto a cadeia só será suspensa quando se aceitar que toda substância é singular, donde nenhuma substância é universal.

No passo seguinte, Ockham argumenta que embora a substância seja singular, o universal não poderia ser "uma única substância, que existe nas substâncias singulares, mas distintas destas últimas" Disto, seguir-se-ia que um indivíduo não poderia existir se outro já existisse. Fica implícito também, que mesmo que Deus quisesse, não poderia aniquilar um indivíduo sem aniquilar, por consegüinte, todos os outros indivíduos. A relação entre o universal que é posto no indivíduo e que está nos outros é direta, sendo assim, destruindo-se um indivíduo, destruir-se-ia também o universal que está na essência dos indivíduos restantes. Segue-se, então, que o universal não pode estar na substância de Sócrates e de Platão, pois se assim o fosse quando Sócrates não mais existisse, também o universal que é posto nele não mais existiria e em decorrência Platão não poderia existir.

Contudo, não se pode desconsiderar este argumento e dizer que o universal é extrínseco, exterior ao indivíduo. É o que ele mostra no próximo passo. Se o universal existir nas substâncias singulares, então pertence à essência do indivíduo. Assim, o indivíduo seria composto de universais.

No quarto argumento, Ockham persegue ainda a mesma idéia de que se o universal pertence à essência do indivíduo, e se se admitir a verdade desta proposição, então ter-se-ia que admitir que Cristo e Judas teriam a mesma essência, isto significa que se Judas tem uma essência miserável e condenada, assim também seria a de Cristo, ou vice-versa, o que é absurdo. 
Fica claro, portanto, que a substância é "singular e numericamente una", e não pode ser universal. Para Ockham, uma substância não pode ser "várias coisas", e neste caso, ela também não pode ser universal, logo, os adversários estão errados ao conferir o universal na substância. Portanto, a "predicação de vários" - típica do universal - vai ser conferida não às substâncias, mas àquilo que "supõe" por elas, ou seja, os termos nas proposições.

Sendo assim, na seqüência, além dos quatro argumentos citados acima, Ockham vai buscar as autoridades e cita, então, vários trechos de Aristóteles: "É impossível que a substância seja qualquer coisa que é dita universal", ainda, "Não é possível que um universal seja uma substância, como se diz a propósito da substância e do ser, nem que este ser seja uma substância como qualquer coisa, que seria uno, fora dos múltiplos"8

Cita também Averróis, comentando vários trechos em relação a substância e que não é ela no universal, a saber: "No indivíduo, não há substância, a não ser matéria e forma, da qual ele é composto"; "Diremos portanto que é impossível qualquer coisa, dentre o que é dito universal, seja a substância de uma coisa, ainda que por elas se expressem as substâncias das coisas"lo; "É impossível que estas coisas que são partes das substâncias existam por si""; "O universal não é uma substância, nem um gênero"12; "como os universais não são substâncias, é claro que o ente comum, não é uma substância existente fora da alma"13. Com mais estas autoridades Ockham conclui que "nenhum universal é uma substância, qualquer que seja a maneira pela qual se considere". O termo "cão", por exemplo, pode supor por um animal e também por uma constelação, conforme a maneira que se considera. Se na proposição: "o cão é um animal" o termo "cão" supõe por animal, então a proposição é verdadeira, mas se supõe por constelação, então é falsa.

Feito isto, ou seja, após manifestar e desenvolver as suas opiniões, parte para o segundo momento onde apresenta que o "universal é uma intenção da alma ... $e$ que não difere do ato intelectivo" Desta vez, Ockham se utiliza do argumento de Avicena, no Livro V, da Metafísica: o universal pode ser dito de três maneiras: primeiro, "o que é predicado em ato de várias coisas"14; segundo, universal é "a intenção que é possível de predicar de várias coisas"15; e, em último lugar, diz ele: universal "é a intenção da qual nada impede de pensar que ela possa ser predicada de várias coisas"16.

Disso se segue, que o universal é realmente predicado de várias coisas, mas não como os opositores admitem. Um tal universal só pode ser predicado de várias coisas no intelecto, pela significação. Logo, o universal é uma intenção da alma.

\section{III. - Conclusão: Uma resposta nominalista}

Creio então, agora, ser possível a solução nominalista de Guilherme de Ockham, que não considera o universal como uma substância extramental. Diz ele: "nenhum universal é uma substância existente fora da alma"17 tudo que é universal predicável de vários está por sua natureza, na mente. O universal é "uma intenção da alma (...) e que não difere do ato intelectivo" 1 , e é ainda, "o que é predicado em ato de várias coisas" "9, mas não como os opositores (realistas) admitem. Um tal universal só pode ser predicado de várias coisas no intelecto, diz ele, pela significação e não nas próprias coisas. 
Entretanto, Ockham traduz a universalidade à questão da singularidade da predicação das palavras. Segundo ele, os universais possuem um estatuto lógico com a função de apontar as proposições afirmando a universalidade dos particulares, na mente, mas somente pela significação dos termos. Logo, se os termos são signos, e como tais compõem as proposições que "fazem as vezes" naquilo que os indivíduos querem expressar, vale dizer, neste caso, que eles designam coisas e como tais, particulares. Contudo, estes particulares na mente e que não se encontram na realidade extramental, uma vez que são conceitos e não coisas sensíveis, tem uma abrangência universal. Isto significa, que os universais são signos significando algo.

Em função do que foi apresentado, torna-se claro que o caráter peculiar desta solução, está calcada em uma expressão de grande importância na doutrina Ockhamista, ou seja, a suppositio ${ }^{20}$. Então, se os universais são universais pelo significado, por aquilo que eles "substituem" na mente e portanto "um ato intelectivo" vale dizer, que o universal enquanto "intenção da alma" é resultado da suposição.

Com este argumento, utilizando um termo mental carregado de significação fica evidente o erro dos opositores que acreditavam que era a própria coisa singular que carregava o universal. Daí se concluir que, "homem" não é de um indivíduo ou de outro, mas é o conceito de todos.

Portanto, a resposta inserida nesta questão vai contra os adversários que consideravam o universal na substância, o que é impossível. A solução de Ockham, conforme foi mostrado acima, encontra o universal não na realidade sensível, mas no signo, o qual é na mente.

Concluo com um trecho de Aristóteles: "universal é o que sendo algo de uno, é apto por sua natureza, a existir em vários, enquanto singular é o que sendo algo de uno, não pode estar em vários." ${ }^{21}$. Segundo Ockham, Aristóteles diz que o universal não trata das coisas singulares, mas de vários enquanto conceito mental, entretanto enquanto singular é na mente e supõe por vários.

\section{BIBLIOGRAFIA}

GUILLAUME d'OCKHAM. Somme de Logique. Première partie, traduit du latin par Joël Biard, I.E.R., bilingue, Paris, 1988.

ARISTÓTELES. Metafísica. Tradução de Leonel Vallandro, Porto Alegre, Editora Globo, 1969.

DE LIBERA, Alain. La querelle des universaux. De Platon à la fin du Moyen Age. Paris, Éditions du Seuil, 1996.

PORFíRIO. Isagoge. Lisboa, Guimarães Editores, 1994.

\section{NOTAS}

1. Aristóteles. Metafísica. I, 6, 987 b, 4 ss: "Platão aceitou a sua doutrina, sustentando, porém que o problema não dizia respeito às coisas sensíveis e sim a entidades de outras espécies - e, por este motivo, a definição comum não podia versar sobre qualquer coisa 
